Language and Language Teaching Journal http://e-journal.usd.ac.id/index.php/LLT Sanata Dharma University, Yogyakarta, Indonesia

\title{
EMPOWERING ENGLISH WRITING STUDENTS: REFLECTING ON ASPECTS OF THE PROCESS THAT HELPED ME MOST?
}

\author{
Deron Walker \\ California Baptist University, California, USA \\ dwalker@calbaptist.edu \\ DOI: doi.org/10.24071/11t.2017.200202
}

received 2 June 2017; revised 5 July 2017; accepted 30 September 2017

\begin{abstract}
Process-oriented writing instruction has been advocated for both L1 and L2 writing classrooms since the 1960s. Empowering learner autonomy may best occur through non-direct instruction (Rogers \& Freiberg, 1994), engaging students in social learning (Vygotsky, 1978) and creating workshop-like classrooms (Murray, 2004). Any number of techniques can be used, preferably in-sync with each other, to accomplish such an approach. This study will examine the results of some recent action research in the classroom to attempt to ascertain among various process-techniques, designed to accomplish the aforementioned aspects of process-oriented instruction, which techniques (CODA paradigm / rubrics, journals, peer reviews, teacher conferences, etc.) were most useful to developmental students, especially from their own points of view. Student voices were collected through oral presentations, instructor evaluations, and classroom observations in an American classroom where native English speaking and nonnative English speaking writers wrestled with freshman level developmental writing side-by-side.
\end{abstract}

Keywords: journals, peer review, teacher conference

\section{Introduction}

Process writing instruction has been en vogue since the 1960s. Donald Murray (2004), the "writer who taught writing," advocated turning writing classes into workshops and teaching by sitting down and listening to students and by modeling instead of just relying on standup lecture. This is the vision I have adopted and used in my own writing classes, both L1 and L2, for over 20 years. It has served me well. My writing classes have been well evaluated (93-95\% approval at the university level for the past 12 years), and several university presidential writing award winners have emerged from those classes (12 placing in the top 3, 5 winning the award) in the same amount of time. Many students have indeed benefited from this type of instruction as both research and my own experience confirm.

Essentially, there are many techniques which can effectively be used to turn writing classrooms into workshop-style atmospheres. Along with Murray's workshop-orientation, other useful theories include capitalizing on engaging 
students in social learning (Vygotsky, 1978) and implementing instruction in a non-direct style whenever possible to increase learner autonomy and empower student writers to take control and gain voice over their own writing and writing processes. Some useful techniques in writing pedagogy for executing such a theoretical approach, then, include engaging students in prewriting activities such as journaling; training students in peer review and holding peer review sessions with them for each formal paper prior to grading it as a teacher, and conferencing with students about their work as much as possible (Walker, 2006, 2001, 2016). These are all techniques that I personally use in addition to others with the writing classes I teach at California Baptist University, English 103 (remedial freshmen), English 113 (entry level composition), and English 350 (research writing for English majors). The first two classes will be the subject of this paper. The latter research writing class is a bit advanced for examination of what works with the developmental writers who I will address in this presentation.

As mentioned, any worthwhile, theoretically-sound composition course these days, would strive to get into the students' writing processes and empower them by upgrading those processes from prewriting to revision in every phase along the way. Briefly, we will overview some techniques which can be used with either L1 or L2 writing students in a writing course to facilitate the upgrading of their writing processes in a college writing course. First of all, any planning techniques geared toward either invention (generating) of ideas or organizing those ideas may be helpful to the multitude of students who often report staring at a blank computer screen or sheet of paper and complain they have difficulty getting started. Activities such as outlining, brainstorming, webbing / clustering, developing concept charts, journaling and freewriting can all be helpful to enable the student to avoid procrastination and plan and organize more efficiently in order to form the blueprint of his or her essay assignment (Glenn \& Goldthwaite, 2014).

This paper will employ a naturalistic inquiry into representative classes selected that I teach from the basic freshman writing ENG 103 (remedial) and ENG 113 (entry level) series of courses offered at California Baptist University. Although I offer students a handout and explanations regarding all of the aforementioned prewriting activities, I typically focus on having students write reflective journals and free writes as mandatory parts of the course that are integrated into units where students will read model essays and explore various genres of writing, culminating with them writing formal essays representing each genre (ENG 103: narration, process, definition, cause and effect; ENG 113 autobiography, observation, evaluation, and position paper). Many of the previously listed prewriting activities hold value for helping students to plan essays by generating and organizing their ideas (Glenn \& Goldthwaite, 2014). Likewise, I encourage students to incorporate such activities into their "toolbox" of prewriting activities according to their own interests and skills as well as considering the challenges of each writing situation. Nevertheless, I do favor journal writing in general and free writing in particular as a focus for building students' writing processes and supporting other class activities as well. 
Many scholars have noted a wide variety of benefits that journal writing in general and free writing in particular have for L1 and L2 writers. For L1 writers, journals in general and free writes in particular have helped native English speakers move from writer-based to develop reader-based prose (Flowers, 1979), gain practice and confidence over the conventions of the university (Bartholomae, 1985) and more fully develop their ideas and writing skills by being allowed to take risks in a low anxiety environment (Elbow, 1973, 1981, 2000; Glenn \& Goldthwaite, 2014; Murray, 2004). For L2 writers many of these benefits apply and more. Second language writers, in addition to the aforementioned, also are aided in negotiating between the rhetorical writing cultures of the L1 and L2 while also increasing their writing fluency and building an enhanced cultural identity as a second language learner (Walker, 2016; Walker \& Guan Lau, 2011; Xing, Wang and Spencer, 2008). Both L1 and L2 writers can use journals as speaking notes that can facilitate Vygotskian (1978) social learning. Moreover, both L1 and L2 writers may benefit if the journals are also used to support the non-direct instruction of teacher conferencing, peer review, and ethnography (Walker, 2016).

After getting students started with prewrites, reflective journals and free writes, much more needs to be done to aid the other parts of the writing process, namely, drafting and revision. One way that I keep the students clear on expectations of the formal writing assignment is to construct a rubric based on a well explained handout (CODA)---laying down the expectations of the essay in clear and concise terms that are then built into the rubric that the student will see when they receive their writing prompt. The acronym CODA that I use in rubrics to assess writing stands for Controlling Idea, Organization, Development, and Audience (CODA). I have used this rubric successfully to rate student writing in my own research (Walker, 2004, 2006) and in many years of teaching.

On the revision side of the process, students are taught techniques to break down their papers with CODA and the assistance of peer reviews from classmates and teacher conferences using non-direct instruction (Rogers \& Freiberg, 1994; Walker, 2006, 2011). All of these techniques are well established in research as being effective if set up carefully and implemented properly, often in tandem with each other. My many years of teaching experience also bears this out as evidenced in high teacher evaluations, and numerous successes among students, including competing well for and often winning presidential writing awards. Nevertheless, what is not often discussed is how the combination of such techniques is received by students, their voices, and what they personally value most. This paper, then seeks to do just that. Conducting a naturalistic inquiry with some action research, two distinct levels of freshman writing will be examined using student evaluations and end of semester presentations to find out what pedagogical techniques students thought helped them the most to build their processes and become better writers in these classes.

\section{Method}

The method for this qualitative examination of action research was to teach ENG 103 and 113 classes in the usual way by integrating the aforementioned elements of process approach: instruction in prewriting, focus on journals, model 
readings, practice with formal essay with open revision, peer review, teacher conferencing, and explicit instruction in revision and editing strategies. At the end of the semester, students delivered an oral presentation discussing their growth and struggles as writers and where they planned to go from here in terms of development. It is important to note, the prompt for this assignment did not explicitly ask them to discuss what elements in the course were most useful to help their improvement. They were only asked such questions during the question and answer portions of their presentations and only to clarify statements they had already made. Nevertheless, students often did, in an unsolicited manner, discuss what helped them improve the most. This is why the question mark exists in the title of this paper. Students were instructed to reflect on their own writing processes and growth but not necessarily the quality of the course. However, many of them did just that. They reflected on all of it together. Therefore, most of the data on what helped students most came from those oral presentations.

Two recent English freshman writing courses were randomly selected for data analysis in this way: one ENG 103 Writing for University Success (remedial) and one ENG 113 English Composition (standard entry course). In the ENG 103, 20 students began the semester while 14 students completed it successfully with a "Pass" (P) grade as it is a Pass / Fail course. Out of those 20 students, 7 came from Spanish speaking homes, 1 Arabic, 1 Portuguese, and 1 Chinese. Meanwhile, 12 of the ENG 103 students were female while 8 were male, overall. The materials collected from the ENG 103 course included 12 presentations (7 from females 5 from males) that yielded useful data, meaning they mentioned elements of the course in addition to their own growth as writers.

In the English 113 course, 22 students started the course while 18 completed it successfully with a grade $\mathrm{C}$ - or higher and made presentations. In terms of gender, 13 were females while 9 were males. Out of the original 22 students, 10 came from homes where Spanish was spoken, 2 Arabic, 2 Tagalog, and 1 Chinese. Thus, there were a large number of what we may classify L2 writers in both of these freshmen writing courses. The ENG 113 course produced 14 total presentations ( 8 from females and 6 from males) with data useful for analysis in the same manner. Notes were taken on the presentations by the instructor who used a key word corpus search by hand to find terms or synonyms to the key terms for the purpose on analyzing student growth, struggles, and parts of their processes that student felt were improved by which techniques with results tabulated and discussed.

\section{Findings and Discussion}

The oral presentation assignment that concluded my ENG 103 and ENG 113 courses was the same identical assignment. The assignment called for students to make a 5-10-minute oral presentation of their work for the entire semester highlighting the growths and struggles of their writing and writing process while reflecting on their areas of improvement and continued struggle. The purpose was to provide students with oral communication experience while also cultivating reflective and higher order critical thinking skills. Table 1 below illustrates areas where ENG 103 students indicated growth and struggle in their 
writing and writing processes. Table 2 delineates student responses for what they believed helped them the most with their writing process and writing improvement.

Table 1. ENG 103 Students Professed Areas of Growth and Continued Struggle

\begin{tabular}{|c|c|c|}
\hline Area & Growth & Struggles \\
\hline $\begin{array}{l}\text { Outlining } \\
\text { Organization }\end{array}$ & 6 & 2 (1 choppy paragraphs) \\
\hline Detail / Argument & $\begin{array}{l}5(\mathrm{t} \text {-chart, } \\
\text { brainstorm })\end{array}$ & 4 (1 lack examples) \\
\hline Confidence & 5 & \\
\hline Prewriting Activities & 4 & 0 \\
\hline Transitions & 3 & 0 \\
\hline $\begin{array}{l}\text { Grammar: Syntax / } \\
\text { Punctuation }\end{array}$ & 3 & $\begin{array}{ll}10 & (5 \\
\text { "spelling") }\end{array}$ \\
\hline Vocabulary & 2 & 0 \\
\hline Thesis & 2 & 1 \\
\hline Intro & 2 & 1 \\
\hline $\begin{array}{l}\text { Openness "embracing } \\
\text { critique" }\end{array}$ & 2 & 0 \\
\hline Revision & 2 & 0 \\
\hline Conclusion & 2 & 2 \\
\hline MLA / APA style & 1 & 2 \\
\hline Time Management & 1 & 1 \\
\hline Creativity & 1 & 0 \\
\hline Timed Essay & 1 & 0 \\
\hline Less emotion & 1 & 0 \\
\hline
\end{tabular}

Table 2. Techniques ENG 103 Students Reported as Helpful to Their Writing or Their Processes

\begin{tabular}{l|l} 
Peer Review & 8 \\
\hline Free write & 6 \\
\hline Written Instructor Feedback & 3 \\
\hline Journals & 2 \\
\hline Looping & 2 \\
\hline Timed Essay & 1
\end{tabular}

Taken together, Tables 1 and 2 tell a story about how students felt concerning their progress, struggles and what helped them in ENG 103. For the most part, the two tables represent a consistency in the findings. The ENG 103 students reported the most growth in organization, detailed argument, prewriting and confidence. From journal writing to CODA to peer review and teacher conferencing, all working in tandem, this is what the writing course was designed 
to do while using a research-based process approach. According to the students (10 of 12 respondents) who took the class, emphasis on prewriting invention activities such as free write (6), journals (2), and looping (2) was instrumental in helping them to organize more effectively and produce more detailed arguments, as it should. In respect to journals and free writes, one of the most memorable student comments was, "Journals were great because I could write about a topic I knew about or wanted to learn about. Journals really helped me organize what I was going to write about" (JO). Another student remarked on the fluency and reflective nature of free writes and journals, "Free writes caused me to write about topics or issues that I had an opinion on helped me to get used to typing short papers in a limited amount of time...great practice for analyzing others papers as well as my own "(AK).

On the revision side, ENG 103 students valued feedback greatly in many forms (11-12 respondents), especially peer review (8) and instructor written feedback (3). Successful peer review sessions often build confidence in developing writers as they gain confidence in hearing both encouragement as well as criticism from peers and internalize writing standards by evaluating them in their peers' writing as well as their own. One student greatly appreciated the revision tips received, "The strategies that I have learned to help improve my runon sentences is re-reading the paper a couple of hours after writing it or waiting a couple of days and reading it OUT LOUD...that's the best advice ever" (AE).

Table 3 below illustrates areas where ENG 113 students indicated growth and struggle in their writing and writing processes. Table 4 delineates student responses for what they believe helped them the most with their writing process and writing improvement.

Table 3. ENG 113 Students Professed Areas of Growth and Struggle

\begin{tabular}{l|l|l} 
Area & Growth & Struggles \\
\hline Thesis & 6 & 0 \\
\hline $\begin{array}{l}\text { Outlining } \\
\text { organization }\end{array}$ & 5 & 2 \\
\hline Detail / Argument & 4 & 6 (1 counterargument) \\
\hline MLA / APA Style & 4 & 4 (APA 2) \\
\hline $\begin{array}{l}\text { Grammar: Syntax } \\
\text { Punctuation }\end{array}$ & 3 & 10 (Punctuation 6) \\
\hline Motivation & 3 & 0 \\
\hline Time Management & 3 & 3 \\
\hline Writing Skills & 3 & 0 \\
\hline Confidence & 2 & 0 \\
\hline Prewriting Activities & 2 & 0 \\
\hline Seeking Help (tutor) & 2 & 0 \\
\hline Spelling & 2 & 0 \\
\hline Reading Analysis & 1 & 0 \\
\hline Sources & 1 & 0 \\
\hline Transitions & 1 & 1
\end{tabular}




\begin{tabular}{l|l|l} 
Vocabulary & 1 & 1 \\
\hline Revision / Audience & 1 & 1 (Audience)
\end{tabular}

Table 4. Techniques ENG 113 Students Reported as Helpful to Their Writing or Their Processes

\begin{tabular}{l|l} 
Instructor Writing Conferences & 10 \\
\hline Peer Review & 8 \\
\hline CODA & 6 \\
\hline Free writing & 4 \\
\hline Readings (Models) & 4 \\
\hline Workshop Sentences on Board & 2 \\
\hline Writing Feedback & 1 \\
\hline Journals & 1 \\
\hline Prewriting & 1 \\
\hline Tutor & 1 \\
\hline Office Hours & 1
\end{tabular}

Taken together, Tables 3 and 4 tell a story about how students felt concerning their progress, struggles and what helped them in ENG 113. For the most part, the two tables represent a consistency in the findings. In Table 3, ENG 113 students most commonly reported that their greatest improvement occurred in thesis (6), organization (5), detail (4), and MLA / APA style (and source citation). These same ENG 113 students elaborated overwhelmingly that feedback in the form of instructor conferences (10-14) and peer review (8-14) were most helpful to them. Close behind in importance to students ranked CODA (6), free writing (4), and the use of model essays (4). In ENG 113 students' own words concerning free writing and journaling, "Journal Discussions helped because not everyone had the same opinions. We could get ideas from others" (MB). However, in ENG 113, most of the memorable quotes revolved around feedback received. Some of it praised peer review, "After reviewing myself I have my roommates or my best friend peer review" (AM). Most of it credited the effectiveness of writing conferences with the course instructor, especially in combination with other techniques such as use of model essays, "Office hours and conferences helped me...readings were fun to read and provided models" (CT)...or CODA, "CODA Helped me to control idea and organize...talking with Professor W. let you know what is wrong" (MA). As one student put it, the combination of all these techniques together in a writing course, properly sequenced and executed, can be powerful, "Conferences 1-1 actually explains to you why...free writing helped with speed...reading analysis teaches what is important in essays" (JR).

How do the two classes compare? The results appear to be very similar. In ENG 103, the remedial course, students reported the most improvement in organization, detail and confidence. Similarly, in ENG 113, students reported the greatest gain in thesis, organization, detail and MLA / APA. Thus, organization and detail were obviously prioritized in both classes and prized by students as a 
valuable gain in their skills in both situations. It is very likely, then that the greater emphasis on thesis and MLA and APA in ENG 113 may represent more of a difference in the scope and nature of the class than any other factors. After all, the same instructor taught both classes largely in the same manner in terms of techniques and emphasis. However, ENG 113 ends with a small research paper and greater emphasis on MLA / APA source citation. ENG 103 has no such research paper. ENG 113 also has more skilled writers who may be starting to get a feel for proper thesis writing, which is emphasized in both courses. Likewise, both classes valued both prewriting free writes and other prewriting activities. Nevertheless, while students in both courses valued feedback, in ENG 113 instructor writing conferences received much greater credit as did CODA (establishing clear expectations for feedback and grading) for helping students to improve. This is probably due to the greater complexity of the ENG 113 course. In ENG 103 students write "mini-essays (1-3 paragraphs) on skill sets such as narration, process, definition, etc. Meanwhile, in ENG 113 students write more challenging full essays on autobiography, observation, evaluation and position paper.

\section{Conclusion}

Process approaches to writing instruction are student-centered by nature. Half a century of process-oriented research has delivered us a set of techniques that carry out writing instruction effectively when used appropriately, as designed, especially in tandem, with clear theoretical understanding of how they work. Few studies, however, capture student voices regarding their own reflection on improvement and struggle in writing course and what they feel works best for them. Given that process-based instruction is a student-centered approach, this seems odd. Student voices may add greatly to our understanding of how and why and in what measure these techniques are effective with different students at various levels. Soliciting student voices in this way adds to our understanding plus it benefits students by having them to reflect on and articulate their growth, struggles, and means of improving. This study is somewhat limited in terms of generalizability as it is simply one naturalistic inquiry of action research, yet it represents a good start for incorporating more student voice into our discussions of process theory and techniques used in writing classes both for L1 and L2 writers. More and larger studies, perhaps of mixed-methods design would be useful as a future direction in the fields of L1 and L2 pedagogy along these lines.

\section{References}

Bartholomae, D. (1985). Inventing the university. In M. Rose (Ed.), When a writer can't write: Studies in writer's block and other composing process problems (pp.134-165). New York: Guilford Press.

Elbow, P. (1973). Writing without teachers. New York: Oxford University Press.

Elbow, P. (1981). Writing with power. New York: Oxford University Press.

Elbow, P. (2000). Everyone can write. New York: Oxford University Press.

Flower, L. (1979). Writer-based prose: A cognitive basis for problems in writing. College English, 41(1), 19-37. 
Glenn, C., \& Goldthwaite, M. A. (2014). St. Martin's guide to teaching writing ( $7^{\text {th }}$ ed.). New York: Bedford.

Murray, D. (2004). A writer teaches writing. Boston, MA: Heinle.

Rogers, C., \& Freiberg, J. J. (1994). Freedom to learn ( $3^{\text {rd }}$ ed.). New York: Macmillan.

Vygotsky, L. S. (1978). Mind in society: The development of higher psychological processes. Cambridge, MA.: Harvard University Press.

Walker, D. (2004). Contrastive rhetoric teaching methods for English as a Foreign Language (EFL) university students (Unpublished doctoral dissertation, Southern Illinois University, Carbondale).

Walker, D. (2006). Improving Korean university student EFL academic writing with contrastive rhetoric: Teacher conferencing and peer response can help. Journal of Asia TEFL, 3(4), 71-111.

Walker, D. (2011). How to teach contrastive (intercultural) rhetoric: Some ideas for pedagogical application. New Horizons in Education, 59(3), 71-81.

Walker, D., \& Guan, L. J. (2011). Journaling and journeying toward academic excellence. Paper presented at the 9th Hawaii International Conference on Education, Honolulu, Hawaii.

Walker, D. (2016). The Journal and the Journey from Contrastive to Intercultural Rhetoric. doi: 10.5176/2251-3566_L316.51

Xing, M., Wang, J., \& Spencer, K. (2008). Raising students' awareness of crosscultural contrastive rhetoric in English writing via an e-learning course. Language Learning and Technology, 12(2), 71-93. 